\title{
Peranan Radio Komunitas Agro dalam Pelayanan Informasi Pertanian di Desa Pangalengan
}

\author{
Teuku Winnetou dan Iwan Setiawan
}

\begin{abstract}
The purpose of this research are to acknowledge the performance communication of radio, the role of radio and the constrains radio faces. The reseach wich implemented in Radio Komunitas Agro at Pangalengan Village used qualitative design with case study research method. The primery data collected with indeep interview from the respondents wich choice using snowball sampling technique. Informations and data collected were analized descriptively.

The outcome of this research indicated, that: (1) generally, performance of sources, message,

channel (tools and equipment), participation of users and communication effect of radio are getting from its own community. Especially, the messages are still domination

of entertainment, tools and equipment used are still under the standard and still significantly

are community which not access to radio transmissions; (2) Agro community radio

have perseption by its hearer wich are positive, but not significant role in serving agricultural information for community; and (3) the constrains of the community radio are fund problems, facilities problems, management problems, human resource (announcer) problems, geographical conditions and supports from the local authority or asosiation.
\end{abstract}

Kata kunci: peranan radio komunitas, layanan informasi

\section{Pendahuluan}

Kajian Masyarakat Telematika Indonesia (2001) mengungkap bahwa sebagian besar masyarakat pedesaan di Indonesia sangat terbatas aksesnya terhadap berbagai sumber informasi produktif. Bahkan, mayoritas dari mereka bersifat pasif, serta tidak memahami hak dan kewajibannya dalam berkomunikasi. Lembaga Informasi Nasional (2002) menegaskan bahwa masyarakat pedesaan sangat sedikit memperoleh informasi. Hal itu terjadi bukan hanya karena lemahnya akses masyarakat, tetapi juga disebabkan lemahnya kualitas dan kuantitas pelayanan informasi dari berbagai sumber informasi (terutama media massa).

Menurut Scott (1993) dan Soetrisno (1999), sebagian besar masyarakat pedesaan berprofesi sebagai petani, karena sebagian besar dari petani di pedesaan menguasai dan mengusahakan lahan kurang dari 0,5 hektar, maka mereka dikategorikan sebagai petani kecil (peasant). Menurut Badan Informasi dan Komunikasi Nasional (2000), akses petani kecil terhadap sumber informasi dan berbagai sumberdaya produktif lainnya, masih berada pada kondisi yang lemah. Myerson (2003) menganalisis bahwa hal itu terjadi karena sumber 
informasi (terutama media massa) yang jumlah, jenis dan eskalasinya terus meningkat, semakin komersial dan tidak senantiasa menyediakan informasi yang dibutuhkan oleh masyarakat pedesaan.

Penelitian Iwan Setiawan (2002) di Kab. Bandung, mengungkap bahwa kinerja layanan informasi pertanian dari radio dan televisi tergolong lemah (10,03\%). Keadaan serupa juga ditemukan oleh Feder dan Slade di pedesaan India dan Grandstaff dan Grandstaff di Thailand (Reijntjes et al., 1999:54). Di India dan Thailand, informasi petani yang bersumber dari siaran radio hanya 910 persen. Padahal, untuk sebuah pembaharuan pertanian, 78 persen petani di Belanda mendapatkan informasi dari radio atau media massa. Menurut Rivera (1990), hal itu terjadi karena media komunikasi massa yang eksistensinya terus meningkat jenis dan jumlahnya, semakin komersial. Bahkan, menurut Habermas (2004), media komunikasi massa bukan hanya sangat komersial, tetapi juga eksploitatif.

Minimnya kualitas layanan informasi pertanian dari media komunikasi massa kepada masyarakat pedesaan, telah mendorong tumbuh-kembangnya media-media komunikasi alternatif di pedesaan, salah satunya adalah radio komunitas. Secara historis-politis, Peraturan Pemerintah (PP) No. 55 Tahun 1970 telah mengatur keberadaan radio komunitas. Dalam PP tersebut disebutkan adanya dua jenis radio di Indonesia, yaitu radio komersial dan radio nonkomersial. Radio komunitas dapat diklasifikasikan sebagai radio nonkomersial, karena sebagian besar siarannya berisi tentang dinamika, kebutuhan dan layanan untuk suatu komunitas. Komunitas (community) berarti "semua orang yang hidup di suatu tempat" atau "sekelompok orang dengan kepentingan atau ketertarikan yang sama."

Berbeda dengan radio komersial, perkembangan radio komunitas di Indonesia mengalami banyak hambatan, terutama menyangkut legalitas dan kepemilikan frekuensi. Kedua hambatan tersebut baru terselesaikan setelah Pemerintah RI mengesahkan UU Penyiaran No. 32 Tahun 2002. Tahun 2002 merupakan awal menjamurnya radio komunitas di Indonesia. Karakteristik dan keberadaan radio komunitas yang cukup unik, telah menarik perhatian publik dan penggagas dunia penyiaran tanah air. Sejalan dengan itu, terbentuk pula jaringan radio komunitas yang berperan sebagai wadah berkumpulnya para pelaku radio komunitas untuk memecahkan masalah, melakukan bimbingan dan peninjauan.

Hingga kini (2008), terdapat tiga jaringan utama radio komunitas di Indonesia, yaitu Jaringan Radio Komunitas Indonesia (JRKI), Jaringan Radio Suara Petani (JRSP), dan Jaringan Radio Komunitas Suara Petani (JRKSP) HKTI. JRKI yang didirikan pada 2002, merupakan jaringan berskala nasional. Pewilayahannya dilakukan berdasarkan batas administrasi propinsi, seperti JRK Jawa Barat dan JRK Yogyakarta. Berbeda dengan JRKI, JRSP dan JRKSP justru lahir dari kreativitas komunitas petani di pedesaan. Proses berdirinya pun lebih didasari oleh kebutuhan komunitas yang bersangkutan, sebagai perwujudan hak asasi manusia (Rachmiatie, 2007).

Berdasarkan laporan CRI (2002) dalam Atie Rachmiatie (2007), di Indonesia terdapat sekitar 152 radio komunitas dan 57 di antaranya terdapat di Jawa Barat. Berdasarkan jumlahnya, Bandung merupakan salah satu daerah yang memiliki cukup banyak radio komunitas yang dinyatakan layak oleh Komisi Penyiaran Indonesia Daerah (KPID) Jawa Barat. CRI (2002) mencatat bahwa di Bandung terdapat sekitar 17 radio komunitas, 9 stasiun radio di antaranya terdapat di Kab. Bandung. Salah satu kecamatan di Kab. Bandung yang memiliki radio komunitas adalah Pangalengan. Di Pangalengan, terdapat 4 (empat) stasiun radio komunitas. Salah satunya adalah radio komunitas Agro yang berbasis komunitas petani. Secara historis-empiris, radio komunitas Agro telah berdiri dan beroperasi sejak 5 Juli 2005.

Penelitian ini bertujuan untuk mengungkap, bagaimana kinerja komunikasi radio komunitas agro setelah beroperasi hampir tiga tahun, apakah radio komunitas Agro mampu memberikan pelayanan informasi pertanian yang layak kepada komunitasnya, dan apa saja kendala yang dihadapi oleh radio komunitas Agro. 


\section{Metode Penelitian}

Objek dalam penelitian ini adalah pengelola radio komunitas Agro dan komunitas pendengarnya yang berada di daerah penelitian, yaitu di radio komunitas Agro FM di Jalan Kecamatan Lama No.211, Tanimukti RT.01/17, Pangalengan, Kab. Bandung, Jawa Barat. Pemilihan radio komunitas dan lokasi penelitian dilakukan dengan pendekatan purposive sampling. Penelitian ini menggunakan desain kualitatif dengan metode studi kasus (case study). Pengumpulan data sekunder dilakukan melalui studi literatur (desk study), sedangkan pengumpulan data primer dilakukan melalui wawancara mendalam (indepth interview) dengan pengelola radio komunitas agro dan dengan komunitas pendengarnya. Responden dari komunitas pendengar diperoleh melalui teknik snowball sampling. Data-data yang diperoleh dianalisis secara deskriptif.

\section{Pembahasan}

\subsection{Kinerja Komunikasi Radio Agro}

Kinerja radio komunitas Agro adalah performance komunikasi di dalam dan dari radio komunitas Agro, yang dapat dilihat dari sumber informasi, pesan yang disiarkan, media yang digunakan, komunitas yang menerima, dan efek siaran radio komunitas terhadap komunitasnya. Berdasarkan hasil penelitian diketahui bahwa:

(1) Informasi yang disiarkan oleh radio komunitas Agro diperoleh dari berbagai sumber, seperti radio, televise, dan media cetak komersial. Sumber lainnya adalah tabloid dari badan narkotika nasional, tabloid dari departemen pertanian, buletin dari dinas peternakan kabupaten, dan dari lingkungan komunitasnya. Secara kelembagaan, radio Agro berada dalam JRKSP-HKTI, namun HKTI sendiri tidak banyak berperan, baik dalam penyediaan informasi maupun tenaga penyuluh (pemateri). Pada kenyataannya, pengisi acara siaran radio Agro lebih banyak mengandalkan pengurus dan partisipasi sukarela dari komunitas pendengarnya;

(2) Komposisi informasi (pesan) yang disiarkan oleh radio komunitas Agro kepada komunitasnya masih menampilkan kinerja yang belum seimbang. Komposisi materi siaran masih didominasi oleh hiburan (55 persen), informasi (25 persen), pendidikan (15 persen), dan iklan layanan masyarakat (5 persen).

(3) Bagi komunitasnya, radio komunitas Agro bukan hanya sekadar sumber informasi, tetapi juga merupakan media untuk menyampaikan aspirasi. Secara riil, peralatan radio komunitas Agro masih sangat sederhana. Daya pancarnya rendah dan terbatas, yakni sekitar $2 \mathrm{~km}^{2}$ sampai $4 \mathrm{~km}^{2}$, tergantung kondisi topografi. Jika dibandingkan dengan standar peralatan atau fasilitas yang layak untuk sebuah radio komunitas, maka radio Agro masih berada di bawah standar. Kebocoran gelombang merupakan masalah yang paling sering muncul, di samping masalah kualitas peralatan lainnya. Keadaan tersebut terjadi karena masih lemahnya kemampuan keuangan radio komunitas Agro. Namun, secara administrasi, radio Agro sudah legal, karena sudah memiliki izin siaran dari KPID Jawa Barat.

(4) Radio komunitas Agro merupakan radio yang didirikan dari, oleh, dan untuk komunitasnya. Oleh karena itu, siarannya sangat bergantung kepada partisipasi aktif komunitasnya. Menurut pengurus radio Agro, "sebagian besar (76,2 persen) komunitas sudah cukup aktif dalam acara-acara radio Agro. Walaupun keterlibatannya belum rutin, dan masih cukup banyak warga yang belum berpartisipasi, namun dengan aktif mendengarkan siaran radio ini saja, kami sudah cukup senang". Pada umumnya, para pendengar lebih didominasi oleh kaum lakilaki yang berusia produktif( 95 persen), mata pencahariannya cukup bervariasi (43 persen petani, 24 persen pedagang, 19 persen PNS dan 9 persen wiraswasta), berpendidikan cukup baik (32 persen tamat SLTP, 29 persen tamat SLTA, dan 29 tamat perguruan tinggi) dan sebagian besar ( 87 persen) mendengarkan 
siaran radio lebih dari satu jam per hari (44 persen mendengarkan 1-3 jam per hari). Hal itu menegaskan bahwa mereka yang selama ini mendengarkan siaran radio komunitas Agro adalah kelompok masyarakat yang tergolong produktif, berpendidikan dan terbuka (kosmopolit).

(5) Masyarakat yang mengetahui dan mendengarkan radio komunitas Agro menyatakan menerima, mendukung dan mengerti bahwa radio tersebut sangat bergantung kepada partisipasi aktif komunitasnya. Sedangkan masyarakat yang belum rutin mengakses siaran radio komunitas Agro menyarankan agar pengelola radio meningkatkan acara yang mengusung budaya lokal, meningkatkan siaran pertanian, mengurangi porsi hiburan dan memperbaiki peralatan pengatur frekuensi agar tidak mengganggu yang lain. Bentuk partisipasi aktif komunitas terhadap radio Agro cukup beragam, mulai dari menjadi penyiar, memberikan pemikiran-pemikiran baru sampai meminta lagu. Namun, secara umum partisipasi aktif komunitas dalam siaran radio Agro masih tergolong rendah.

(6) Terkait dengan substansi dan porsi siaran, masyarakat menyatakan bahwa siaran atau materi yang disiarkan oleh radio komunitas Agro sangat berguna. Secara kuantitatif, 58 persen masyarakat mengetahui substansi siaran radio Agro, namun baru 42 persen yang menyatakan bahwa informasi yang siarkan sangat berguna. Sebagai salah satu media massa, efek siaran radio Agro hanya mampu menjangkau domain kognitif. Artinya, substansi siaran hanya mampu meningkatkan pengetahuan komunitas pendengarnya.

\subsection{Peran dan Fungsi Radio Komunitas Agro}

Sebagai media massa, radio komunitas Agro sudah seharusnya menjalankan tiga peran dan fungsi sekaligus, yaitu pelayanan informasi, pelayanan pendidikan, dan pelayanan hiburan kepada para pendengarnya. Hasil penelitian mengungkap bahwa:

(1) Radio komunitas Agro berperan dalam pelayanan informasi yang umumnya dibutuhkan oleh warga atau komunitasnya, seperti informasi teknologi pertanian (30 persen), informasi perkembangan pasar (20 persen), berita sekitar daerah (10 persen), kesehatan (25 persen) dan siraman rohani (15 persen). Informasi teknologi pertanian yang diberikan pada umumnya berupa aplikasi teknologi tepat guna (rekomendasi peralatan yang digunakan), teknik pemberantasan hama dan penyakit tanaman/hewan, pemilihan bibit uggul, pemupukan yang tepat, dan teknik beternak (terutama sapi dan kelinci). Informasi teknologi pertanian juga disampaikan dalam bentuk iklan-iklan pertanian. Informasi pemasaran yang disiarkan berupa perubahan tingkat harga, trend komoditas dan posisi harga tawar komoditas. Berita sekitar daerah diberi nama "warta agro", yang berisi informasi yang terjadi di sekitar Pangalengan. Informasi kesehatan bersifat umum, sehingga pengemasannya diintegrasikan dengan hiburan (musik), tentu sebagian besar (70 persen) berisi informasi kesehatan dan perawatan kecantikan remaja. Sedangkan untuk siaran rohani, masih belum memiliki jadwal yang jelas, terutama terkendala oleh pemateri. Oleh karena itu, seringkali dilakukan dalam bentuk pemutaran musik-musik bernuansa Islami.

(2) Radio komunitas Agro juga berperan didalam pelayanan informasi pendidikan yang dibutuhkan oleh warga atau komunitasnya, seperti program penyuluhan pertanian dan peternakan (30 persen), program informasi pertanian (20 persen), program pendidikan bahasa Inggris ( 30 persen) dan program wisata budaya (20 persen). Program penyuluhan/ diskusi pertanian dan peternakan merupakan program favorit atau unggulan, karena pimpinan umum radio Agro juga berprofesi sebagai penyuluh lapangan pertanian dan peternakan. Secara umum, informasi 
penyuluhan diperoleh dari dinas pertanian dan peternakan. Namun, pimpinan radio Agro mengatakan bahwa "untuk menjalankan program penyuluhan itu tidak mudah, karena dibutuhkan tenaga ahli (baik penyuluh pemerintah, swasta maupun swadaya). Untuk memanggil atau mendatangkan seorang penyuluh atau tenaga ahli, jelas membutuhkan biaya, sekalipun penyuluh tersebut adalah seorang kerabat dekat". Karena demikian, maka acara yang mendapat respon baik ini, semakin jarang terdengar.

(3) Selain acara penyuluhan, juga terdapat acara diskusi pertanian yang lebih bersifat dua arah, sehingga memungkinkan bagi para petani untuk berinteraksi dengan petani lainnya, baik secara langsung datang ke studio, maupun melalui telepon. Konsep acara diskusi pertanian yang disiarkan radi Agro serupa dengan acara diskusi yang sering disiarkan di televisi. Permasalahannya, partisipasi para petani masih lemah, baik karena tidak adanya kelompok tani maupun karena faktor kesibukan.

(4) Program pendidikan lainnya yang disiarkan radio Agro adalah belajar bahasa Inggris. Acara ini lebih ditujukan kepada siswa sekolah, baik SD, SMP maupun SMA yang membutuhkan pelajaran tambahan. Radio Agro mengemas program ini dengan cukup baik, dengan menggunakan tenaga ahli setempat. Permasalahannya, program ini tidak dijalankan secara rutin, karena sangat bergantung kepada waktu yang disediakan penyiar yang sifatnya sukarela.

(5) Selain program belajar bahasa Inggris, juga disiarkan program wisata budaya, seperti belajar bahasa Sunda, informasi kebudayaan daerah, cerita pendek dan sebagainya. Tujuannya, selain untuk mendidik anak-anak dan kaum muda, juga untuk melestarikan budaya sunda.

(6) Hiburan merupakan acara radio komunitas Agro yang paling dominan. Wujudnya berupa pemutaran musik, baik musik daerah, nasional maupun musik Barat. Jenis hiburan yang disiarkan oleh radio Agro sangat beragam, mulai dari musik pop Indonesia (15 persen), musik dangdut ( 25 persen), musik barat (5 persen), musik daerah (35 persen), karoke (5 persen), hingga wayang golek (15 persen). Mengingat masyarakat Pangalengan masih kental dengan budaya Sunda, maka wajar jika persentase musik daerah lebih besar dibandingkan dengan musik lainnya. Programprogram yang disiarkan memiliki nama tersendiri, bargantung pada aliran musik yang diberikan, seperti pagoda, satu-dua-tiga, dangiang Sunda, pelangi (pentas lagu nostalgia) dan sempal-sempil.

(7) Seperti halnya musik, wayang golek juga merupakan acara hiburan yang kental dengan budaya masyarakat Sunda. Acara wayang golek memiliki nama siaran "ngaruat budaya". Menurut masyarakat, acara wayang golek sangat positif, menarik dan menghibur. Disamping acara musik dan wayang golek, radio Agro juga memiliki acara karaoke "pentas kabisa", yang merupakan ajang berkumpul dan berinteraksinya komunitas radio Agro. Meskipun belum memiliki jadwal yang rutin, namun komunitas cukup antusias menyambutnya.

\subsection{Permasalahan Radio Komunitas Agro}

Pada kenyataannya, radio komunitas Agro menghadapi banyak permasalahan, baik yang bersumber dari faktor internal maupun dari faktor eksternal. Permasalahan yang bersumber dari faktor internal, meliputi:

(1) Keterbatasan sebuah radio komunitas adalah tidak bersifat komersial. Akibatnya, radio Agro mengalami kesulitan mencari sumber dana. Selama ini, radio Agro hanya mengandalkan bantuan dana dari donatur, sumbangan sukarela, dan permintaan lagu dari komunitas, dana sukarela dari pengurus, dan dari diversifikasi usaha. Manajemen keuangannya pun belum terorganisir atau terbukukan dengan baik dan terperinci, sehingga masih tercampur antara keuangan radio dengan keuangan pribadi pengurus; 
(2) Fasilitas yang dimiliki oleh radio Agro sangat terbatas, bahkan kemampuan peralatan elektronik penunjang siaran pun masih terbilang sederhana dan belum terkomputerisasi dengan benar; dan

(3) Setiap acara, jelas membutuhkan seorang penyiar, minimal sebagai pengantar acara. Pada kenyataannya, meskipun siaran radio komunitas Agro melibatkan partisipasi aktif komunitasnya, namun masih tetap kekurangan tenaga penyiar, baik dari segi kualitas maupun kuantitas. Sifat sukarela dari komunitas tentunya memiliki keterbatasan. Namun, mendatangkan penyiar yang berkualitas tentunya tidak gampang, karena membutuhkan dana tambahan yang sulit untuk dipenuhi.

Sedangkan permasalahan yang bersumber dari faktor eksternal radio Agro, meliputi:

(1) Kondisi wilayah Pangalengan yang berbukitbukit cukup menghambat proses interaksi, komunikasi dan saling bertukar informasi. Daya pancar radio komunitas Agro tergolong rendah (hanya sejauh $2 \mathrm{~km}^{2}$ ). Padahal, wilayah Desa Pangalengan sangat luas. Oleh karena itu, untuk memenuhi kebutuhan informasi sekaligus memperkenalkan radio Agro kepada masyarakat, pihak radio Agro terpaksa meningkatkan daya pancar mereka dengan pendekatan yang kurang legal.

(2) Kurangnya perhatian dan dukungan (baik biaya maupun informasi) yang diberikan oleh pemerintah setempat dan instansi terkait (seperti JRKSP-HKTI). Oleh karena itu, dukungan dana, informasi, pelatihan ataupun tenaga penyuluh pertanian, dari berbagai pihak, termasuk JRKSP-HKTI, sangat diperlukan.

\section{Kesimpulan dan Saran}

\subsection{Kesimpulan}

Radio komunitas Agro merupakan media komunikasi yang bersifat independen, tidak komersial, daya pancar rendah, luas wilayah penyebarannya terbatas dan hanya melayani kepentingan komunitas. Kinerja dari radio Agro sudah cukup baik, hal ini dapat dilihat dari sumber informasi yang tidak sulit untuk dijangkau dan karakteristik komunitas yang merespon baik. Fasilitasnya masih berada di bawah standar kelayakan sebuah radio komunitas. Terkait dengan pelayanan, radio komunitas Agro sudah cukup baik, terutama pada penyediaan materi siaran (informasi, pendidikan dan hiburan). Materi siaran masih didominasi hiburan ( 55 persen), informasi (25 persen), pendidikan (15 persen) dan iklan layanan masyarakat (5 persen). Keberadaan radio Agro mendapat dukungan dari mayoritas warga desa (71 persen) dan tidak ada yang menolak, namun 29 persen masyarakat desa masih belum mengetahui kerberadaannya. Secara umum, radio komunitas Agro dipersepsi positif oleh komunitasnya, namun belum banyak berperan (hanya 36-47 persen) di dalam pelayanan informasi pertanian yang dibutuhkan oleh komunitasnya. Secara riil, radio komunitas Agro masih menghadapi banyak permasalahan, seperti: sumber dana yang tidak mencukupi, fasilitas yang kurang memadai, keuangan yang belum terkoordinasi dengan baik, sumber daya penyiar yang masih kurang (jumlah dan kualitas), kondisi wilayah yang berbukit-bukit dan masih lemahnya dukungan dari Pemerintah Daerah dan instansi terkait.

\subsection{Saran}

Mengingat radio komunitas Agro berlokasi di pedesaan yang berbasis pertanian, maka pihak pengelola sebaiknya menekankan dan meningkatkan penyediaan materi atau siaran lebih kepada informasi agribisnis (baik menyangkut upstream, on-farm, down-stream and supporting system agribisnis). Secara riil, para petani sangat membutuhkan informasi dalam bidang pertanian. Hal ini dapat dilakukan dengan mengurangi porsi siaran hiburan dan membuat program-program pertanian yang lebih inovatif, kreatif, dan aplikatif. Untuk itu, perlu dilakukan peningkatan kualitas sumber daya manusia pengelolanya, kuantitas sumber dana, kualitas fasilitas dan efektivitas materi siaran, baik secara mandiri maupun melalui 
kerjasama dengan institusi terkait (institusi pemerintah, swasta, swadaya dan radio komunitas lain).

\section{Daftar Pustaka}

Atie Rachmiatie. 2007. Radio Komunitas Eskalasi Demokratisasi Komunikasi. Bandung: Simbiosa Rekatama Media.

Badan Informasi dan Komunikasi Nasional. 2000. "Karakteristik Media dan Khalayak Layanan." Laporan Penelitian, Jakarta.

Burhan Bungin. 2007. Penelitian Kualitatif, Komunikasi, Ekonomi, Kebijakan Publik dan Ilmu Sosial Lainnya. Jakarta: Kencana.

Iwan Setiawan. 2002. "Tingkat Keberdayaan Komunikasi Petani dan Faktor Faktor yang Mempengaruhinya." Tesis. Sekolah Pascasarjana Institut Pertanian Bogor.

Lembaga Informasi Nasional. 2002. "Studi Umpan Balik dan Pendapat Publik." Laporan Penelitian LIN, Jakarta.

Masyarakat Telematika Indonesia. 2001.
Myerson, G. 2003. Heidegger, Habermas, dan Telepon Genggam. Jendela, Yogyakarta.

Reijntjes, C., Bartus, H., dan Water-Bayer. 1992. Pertanian Masa Depan. Kanisius, Yogyakarta.

Rivera, W.M., and Gustafson, D.J. 1991. "Agricultural Extension: Worldwide Institutional Evolution and Forces for Change." Amesterdam: Elsevier Science Publishing.

Scott, J. 1993. Perlawanan Kaum Tani. LP3ESPress, Jakarta.

Soetrisno, L. 1999. Pertanian Pada Abad 21. Jakarta: Direktorat Jenderal Pendidikan Tinggi Depdikbud.

Undang-Undang Republik Indonesia nomor 32 tahun 2002 tentang penyiaran. 2003. Jakarta: Lembaga Informasi Nasional, Deputi Bidang Hubungan Antar Lembaga, Direktorat Hubungan Informasi dengan Lembaga Masyarakat dan Media.

Yosal Iriantara. 2004. Community Relations Konsep dan Aplikasinya. Bandung: Simbiosa Rekatama Media 
